\title{
Structure and dynamics of deep-seated slope failures in the Magura Flysch Nappe, outer Western Carpathians (Czech Republic)
}

\author{
I. Baron ${ }^{1,2}$, V. Cilek ${ }^{3}$, O. Krejci ${ }^{1}$, R. Melichar ${ }^{2}$, and F. Hubatka ${ }^{4}$ \\ ${ }^{1}$ Czech Geological Survey, branch Brno, Leitnerova 22, 65869 Brno, Czech Republic \\ ${ }^{2}$ Institute of Geological Sciences, Faculty of Science, Masaryk University, Kotlarska 2, 61200 Brno, Czech Republic \\ ${ }^{3}$ Geological Institute of Czech Academy of Sciences, Rozvojova 135, 16500 Prague, Czech Republic \\ ${ }^{4}$ Kolej Consult \& Servis, s.r.o., Krenova 35, 61200 Brno, Czech Republic
}

Received: 7 May 2004 - Revised: 3 September 2004 - Accepted: 14 September 2004 - Published: 5 October 2004

Part of Special Issue "Monitoring and modeling of landslides and debris flows"

\begin{abstract}
Deep-seated mass movements currently comprise one of the main morphogenetic processes in the Flysch Belt of the Western Carpathians of Central Europe. These mass movements result in a large spectrum of slope failures, depending on the type of movement and the nature of the bedrock. This paper presents the results of a detailed survey and reconstruction of three distinct deep-seated slope failures in the Raca Unit of the Magura Nappe, Flysch Belt of the Western Carpathians in the Czech Republic. An interdisciplinary approach has enabled a global view of the dynamics and development of these deep-seated slope failures. The three cases considered here have revealed a complex, polyphase development of slope failure. They are deep-seated ones with depths to the failure surface ranging from 50 to $110 \mathrm{~m}$. They differ in mechanism of movement, failure structure, current activity, and total displacement. The main factors influencing their development have been flysch-bedrock structure, lithology, faulting by bedrock separation (which enabled further weakening through deep weathering), geomorphic setting, swelling of smectite-rich clays, and finally heavy rainfall. All of the slope failures considered here seem to have originated during humid phases of the Holocene or during the Late Glacial.
\end{abstract}

\section{Introduction}

Deep-seated mass movements are not well understood due to their large scale of deformation, limited applicability and the cost of ground surveys. However, several large gravitational failures of mountain slopes have been described in various countries by many authors (e.g. Schuster and Wieczorek, 2002; Ter-Stepanian, 1966), in Central and Southern Europe (Agliardi et al., 2001; Moser et al., 2002; Zischinsky, 1969), and in the former Czechoslovakia (Nemcok, 1972,

Correspondence to: I. Baron

(baron@cgu.cz; ivobaron@seznam.cz)
1982; Nemcok et al., 1974; Novosad, 1966; Rybar et al., 2000; Zaruba et al., 1966). A general overview of deepseated slope failure investigations has been performed by Crosta (1996). In spite of such amount of published works, the slope-failure classification still remains unclear and inconsistent. We will follow the traditional Czech and Slovak point of view, where the "slope failure" is a broader term for other slope instabilities (Nemcok et al., 1974). In the paper, we consider slope failure to be a set of geological structures and geomorphic features of small and medium scale, which originated due to gravity-induced mass movement and its deforming effect on bedrock and colluvium related to the slope. This term seems to be more distinct than, e.g. a "landslide" of Dikau et al. (1996) as a general term for any other slope instabilities. However, the problem of the classification is not subject of this paper, and it should be discussed more in wider scientific community.

Although the Czech school on slope failures has had a great tradition since the works of Professor Q. Zaruba, a special expansion of any slope instabilities mapping and case studies has occurred since the major floods and landslide activity in the Czech Republic in 1997. Between 1997 and 2003, Czech experts recognized more than 5800 slope failures in the Flysch Belt of the Western Carpathians and within the Carpathian Foredeep in the territory of the Czech Republic; $5-17 \%$ of the landscape has been affected by mass movements in the most hazardous areas. We recognize that deep-seated mass movements are currently one of the main morphogenetic processes in the area of interest (Krejci et al., 2002; Baron et al., 2003), similar to the situation in New Zealand (Korup and Crozier, 2002). These mass movements have resulted in a large spectrum of slope failures, depending on the types of movement and the nature of the bedrock. Attempts to clearly understand the mechanism and kinematics of such large phenomena have been difficult; an integrated multidisciplinary approach is necessary (Agliardi et al., 2001; Clerici et al., 2002; Buccolini et al., 2002). 
Table 1. Clay mineral content in weathered ground in studied slope failures: Q-quartz, M-mica or illite, F-feldspar, K-kaolinite, Sm-smectite, He-hematite, A-anatase, Chl-chlorite, Gy-gypsum, Ca-calcite, Am-amphibole, V-vermiculite, An-anorthite, Na-Sminterstratified minerals (e.g. natrolite-smectite); Expanding clay minerals are in bold letters.

\begin{tabular}{cccc}
\hline sample & landslide & location & clay minerals \\
\hline 1 & Vaculov Sedlo & forest-road cut & Q, Sm, M, K, F \\
2 & Vaculov Sedlo & stable ground & Q, K, M, Chl-SM, F, He \\
3 & Vaculov Sedlo & forest-road cut & Q, K, M, Chl-Sm, Chl-M, F \\
4 & Vaculov Sedlo & forest-road cut, active landslide & Q, K, M, Sm, Sm-Na, F \\
5 & Vaculov Sedlo & forest-road cut, active landslide & Q, K, M, Chl-Sm, F, He, A \\
6 & Vaculov Sedlo & forest-road cut, active landslide & Q, M, Chl, Chl-Sm, F, A \\
7 & Vaculov Sedlo & forest-road cut, active landslide & Q, K, M, Chl, Sm, F, He \\
8 & Vaculov Sedlo & forest-road cut & Q, K. M. Sm, F, He, A, Gy \\
9 & Kopce & shale bed in the flow source area & K, M, Q, F, Chl-Sm, Sl-Sm \\
10 & Kopce & shale bed in the flow source area & Q, Chl, M, Chl-Sm, Chl-Sm, Ca, F \\
11 & Kobylska & forest-road cut, active landslide & Q, Chl, K, M, F \\
12 & Kobylska & forest-road cut & Q, M, Chl, F \\
13 & Kobylska & middle part of landslide & Q, K, M, Chl-Sm, F, He, Chl \\
14 & Kobylska & landslide dam & Q, M, Chl, F \\
15 & Kobylska & stable ground & Q, M, Chl, F \\
16 & Kobylska & pseudo-karst doline & Q, K, M, V, V-M, F, A \\
\hline
\end{tabular}

In this paper, we present results of interdisciplinary investigation and reconstruction of three distinct complex slope failures in the Raca Unit of the Magura Nappe, Flysch Belt of Western Carpathians in the eastern part of the Czech Republic.

\section{Geological and geomorphic settings of the slope fail- ures in the Magura Flysch Nappe}

The area of the Flysch Belt of the Western Carpathians is comprised mainly of alternating claystone, shale, and sandstone layers of Mesozoic and Tertiary age. The Czech portion of the Flysch Belt is an allochthonous nappe system that was thrust over the West European Plate and part of its foredeep from the southeast during Paleogene and Early Neogene orogeny. This system consists of several partial nappe sheets in the Czech Republic, e.g. the Outer Flysch Nappes (Pouzdrany, Zdanice, Silesian, and Subsilesian Nappes) and the Magura Nappe. The tectonically older Magura Nappe is the largest one in the Czech Republic. All of the case-study sites of deep-seated slope failures are located within the Raca Unit of the Magura Nappe. This unit is a fold-belt system with imbricated thin-skinned thrust structure, disturbed by radial faults (Picha et al., 2004). In general, the flysch bedrock is weak and strongly weathered; thus, it is therefore quite difficult to obtain enough relevant data on tectonic structure in the field.

The relief of the Magura Nappe is generally that of uplands, highlands, and mountains up to $1024 \mathrm{~m}$ a.s.l., with major slope inclinations of $10^{\circ}$ to $20^{\circ}$ (58\% of the area). Although slopes steeper than $20^{\circ}$ cover $22 \%$ of the most endangered area of the Vsetin district, most of the slope fail- ures $(71 \%)$ have occurred within the slopes on $10-20^{\circ}$ slopes (Krejci et al., 2002).

The three investigated slope failures are located in hilly terrain near the town of Vsetin (Fig. 1). The Vaculov-Sedlo failure is situated on the southern and western slopes of Ptacnice Hill (830 m a.s.l.) and Prostredni Hill (743 m a.s.l.; $\left.49^{\circ} 23^{\prime} \mathrm{N}, 18^{\circ} 05^{\prime} \mathrm{E}\right)$, at an elevation of 440 to $750 \mathrm{~m}$ a.s.l. (Fig. 2). The surface slope averages $10^{\circ}$ to $15^{\circ}$. The affected mass covers an area of at least of $2.5 \mathrm{~km}^{2}$ and up to 123 million $\mathrm{m}^{3}$ in volume. The failure has developed in flysch rocks of the Beloveza and Solan Formations of the Raca Unit. In general, claystones and rocks of thin-bedded flysch sequences prevail. These rocks are overlain by 10-12-mthick sandstone and conglomerate beds in the eastern part; these beds have been sagged by gravity. The beds are gently folded and, in general, slightly dipping to the SE and NW. The weathered colluvium contains smectite (Table 1). About $90 \%$ of the SE part is forested, while about $50 \%$ of the NW part is covered with meadows and pastures. The NW part is diffusely inhabited, with at least 50 houses directly endangered by the slope failure.

The second slope failure at Kobylska is about $800 \mathrm{~m}$ long and $500 \mathrm{~m}$ wide, with $180 \mathrm{~m}$ of relief between head and toe and a volume of about 16 million $\mathrm{m}^{3}$. This failure affected bedrock at the end of the T-shaped Kobylska valley on the southern slopes of Lesti Hill (899.6 ma.s.1.; $49^{\circ} 23^{\prime} 25^{\prime \prime} \mathrm{N}$, $18^{\circ} 13^{\prime} 20^{\prime \prime} \mathrm{E}$ ). The slope is $14.5^{\circ}$ in the upper part and up to $22^{\circ}$ in the lower part, sloping mainly concurrently (and partly opposite) to the bedding dip. An anticline of the Zlin Formation runs E-W across the landslide area. We have speculated about a tectonic contact between the Beloveza and Zlin Formations within the landslide (Fig. 3). Unfortunately, there is no outcrop that shows this contact. The bedrock is composed 


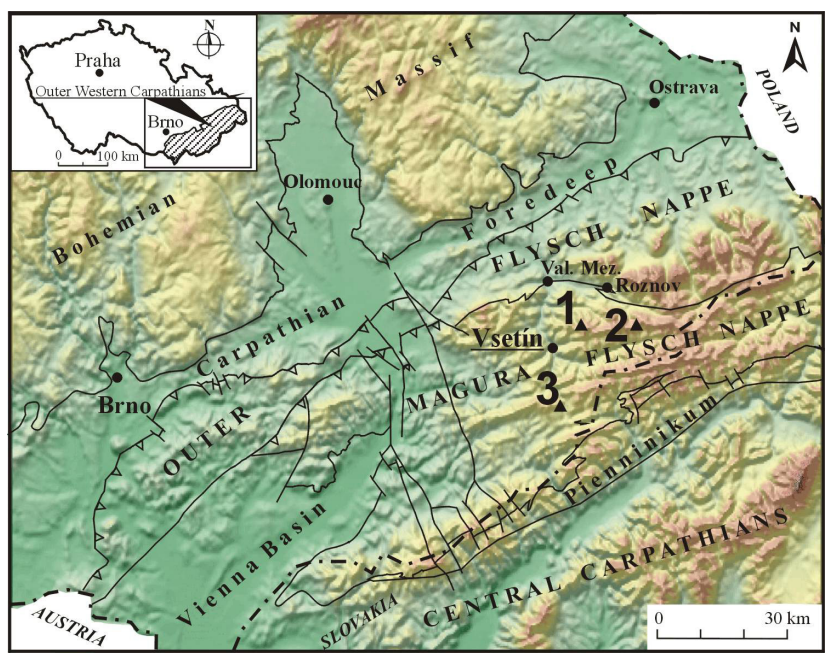

Fig. 1. Digital Elevation Model (DEM) of the Flysch Belt of the Western Carpathians in the Czech Republic. Studied slope failures: 1-Vaculov-Sedlo, 2-Kobylska and 3-Kopce.

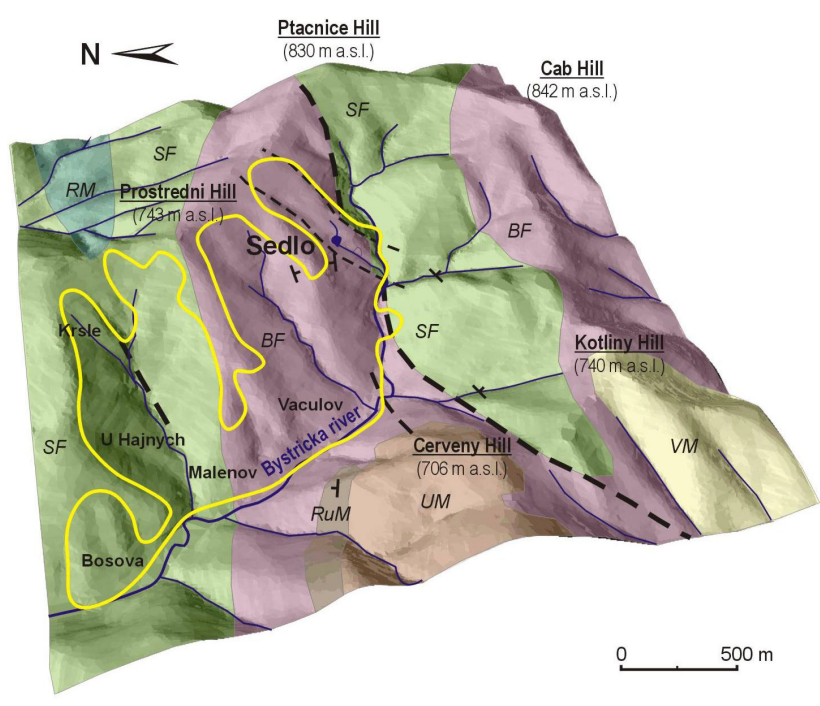

Fig. 2. DEM of the Vaculov-Sedlo slope failure (yellow) with the following geological setting: $B F$-Beloveza Formation, $S F$-Solan Formation (not specified), $R M$-Raztoka Member of the Solan Formation, and the Zlin Formation $(Z F)$ : $R u M$-Rusava Member, $U M$ Ujezd Member and $V M$-Vsetin Member, faults are drawn as dashed lines.

of thin-bedded flysch with occasional layers of sandstone 1$3 \mathrm{~m}$ thick. Shales and colluvium of the Beloveza Formation include swelling clays (Table 1). The area of the landslide is heavily forested.

The third slope failure, the Kopce rock slide, is situated on the northern slope of Kopce Hill (699 m a.s.l.; 49 $13^{\prime} 11^{\prime \prime} \mathrm{N}$, $18^{\circ} 02^{\prime} 34^{\prime \prime} \mathrm{E}$ ). This slide covers an area about $500 \mathrm{~m}$ long and $400 \mathrm{~m}$ wide (Fig. 4). A debris flow about $250 \mathrm{~m}$ long, located on the eastern slope, is probably part of the failure. The head of the failure is at elevation of $675 \mathrm{~m}$ a.s.l.; the toe is located at about $500 \mathrm{~m}$ a.s.l. The slope failure has a volume

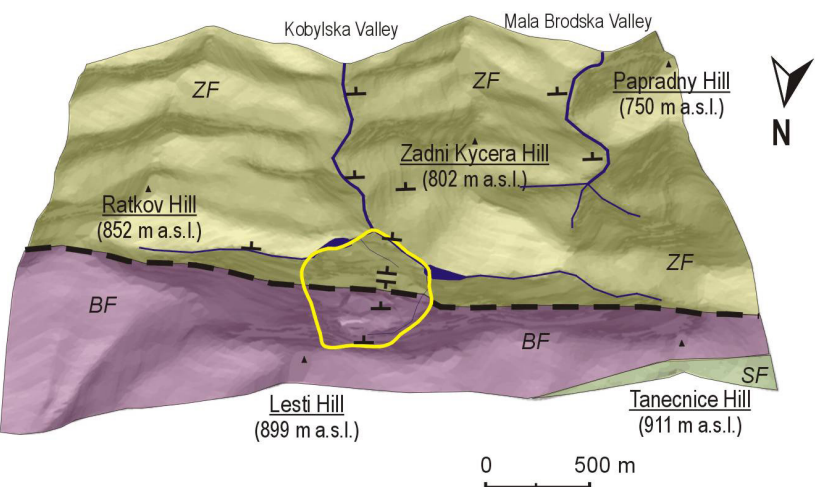

Fig. 3. DEM of the Kobylska slope failure (yellow) with the following geological setting: $B F$-Beloveza Formation, $Z F$-Vsetin Member of the Zlin Formation, faults are drawn as dashed line.

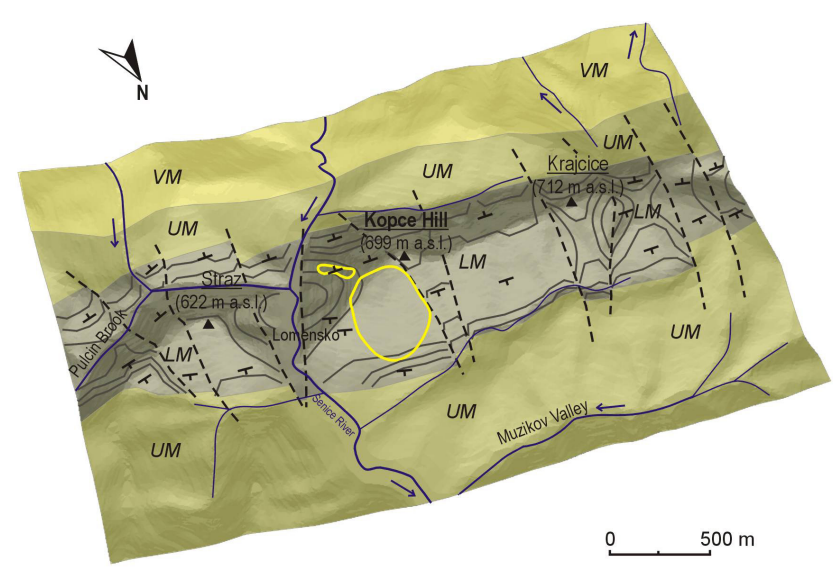

Fig. 4. DEM of the Kopce rock slide and debris flow (yellow) with the following geological setting: the Zlin Formation: $U M$-Ujezd Member, $L M$-Luhacovice Member and $V M$-Vsetin Member.

of as much as 10 million $\mathrm{m}^{3}$ of bedrock and colluvium. The bedrock is composed of sandstone and conglomerate beds $15-20 \mathrm{~m}$ thick alternated with sequences of weaker claystone, shale, and thin-bedded sandstone (total thickness 10 $15 \mathrm{~m}$ ). These beds are related to a ramp-anticline of the Luhacovice Member, Zlin Formation (Fig. 4). The anticline strikes WSW-ENE and is disturbed by several transverse faults. One of these faults is expected to limit the landslide from the $\mathrm{W}$; the others probably influenced the deep transverse cut of the Senice River. The anticline ridge is about $900 \mathrm{~m}$ wide at the foot of the eastern slopes; the ridge amplitude above the Senice River is about $260 \mathrm{~m}$. The original surface sloped from $5^{\circ}$ to $25^{\circ}$ at the place of the landslide, and up to $40^{\circ}$ on the eastern slopes. There are often structural surfaces on the bedding planes of exhumed competent sandstone, and steps on the faces of this beds due to selective terrain denudation. The claystones include swelling clays (Table 1). The entire slope-failure area is forested with an 80-100 year-old mixture of spruce, beech, and maple trees. 


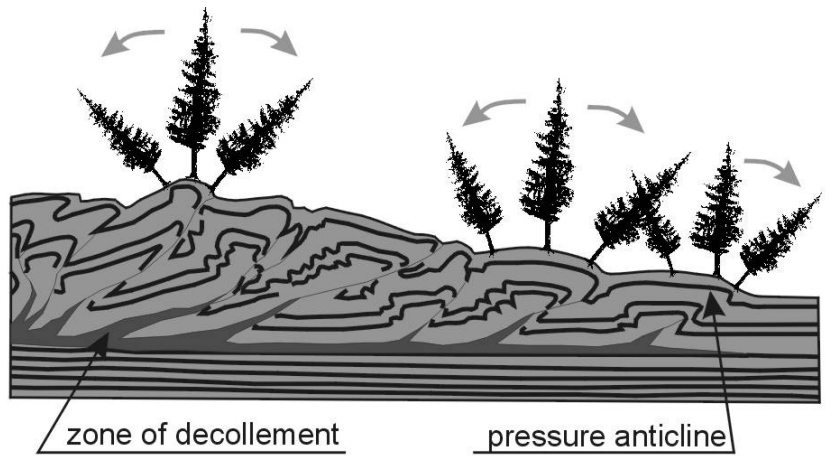

Fig. 5. Suppositional cross section of the frontal part of a landslide with pressure folds structure and "fan-like" tree tilting on anticlines (the figure based on Yamada et al. 2004).

\section{Methods}

The study of large-scale slope-failure phenomena, such as deep-seated rock slides, requires a thorough and interdisciplinary approach. In our study, we used the various methods of Quaternary geology, geomorphology, geophysics, engineering geology, mineralogy, and sedimentology in an attempt to fully understand the problem. The use of these individual methods differed at each site due to local conditions and financial support.

We first undertook detailed geomorphic mapping at all sites at a scale 1:5000. We located the limits of the failures and looked for basic slope-failure features (see the legend on Fig. 6a). We mapped shape and distribution of scarps, cracks, slope-failure blocks, pressure folds, accumulation toes, boulders, rocky outcrops, swamps, erosional scarps, etc. We recorded "slope-failure blocks" as any relatively intact blocks of bedrock with preserved original bedding and conserved original surface shape. Elongated elevations of deformed mass with typical "fan-like" tree tilting on them (Fig. 5) we regarded as "pressure folds" and "pressure brachy-anticlines" (pressure ridges of Beetham et al., 2002). Additionally, geological and structural mapping of the sites was performed.

The deeper structure was investigated by using Pulse EKKO 100A ground-penetrating radar (GPR). This tool provided continual 2D imaging of the subsurface structure; especially, slip surfaces, softened masses, buried surfaces, pond sediments, tectonic faults or weathered and watersaturated zones were recognised due to contrast of their relative dielectric permittivity (Conyers and Goodman, 1997). We recorded wave reflectors at depths of as much as up to 20 to $40 \mathrm{~m}$ below the ground surface (when the material was dry and soft). The antennae separation was $4 \mathrm{~m}$, trace spacing $0.5 \mathrm{~m}$ and data collection 1000-3000 ns with a frequency of $50 \mathrm{MHz}$. The record was processed with conventional software (Annan, 1997). Although the image of the subsurface structure obtained from GPR was sometimes ambiguous, we were able to establish generalised models of the slope failures. The length and number of profiles was limited by the
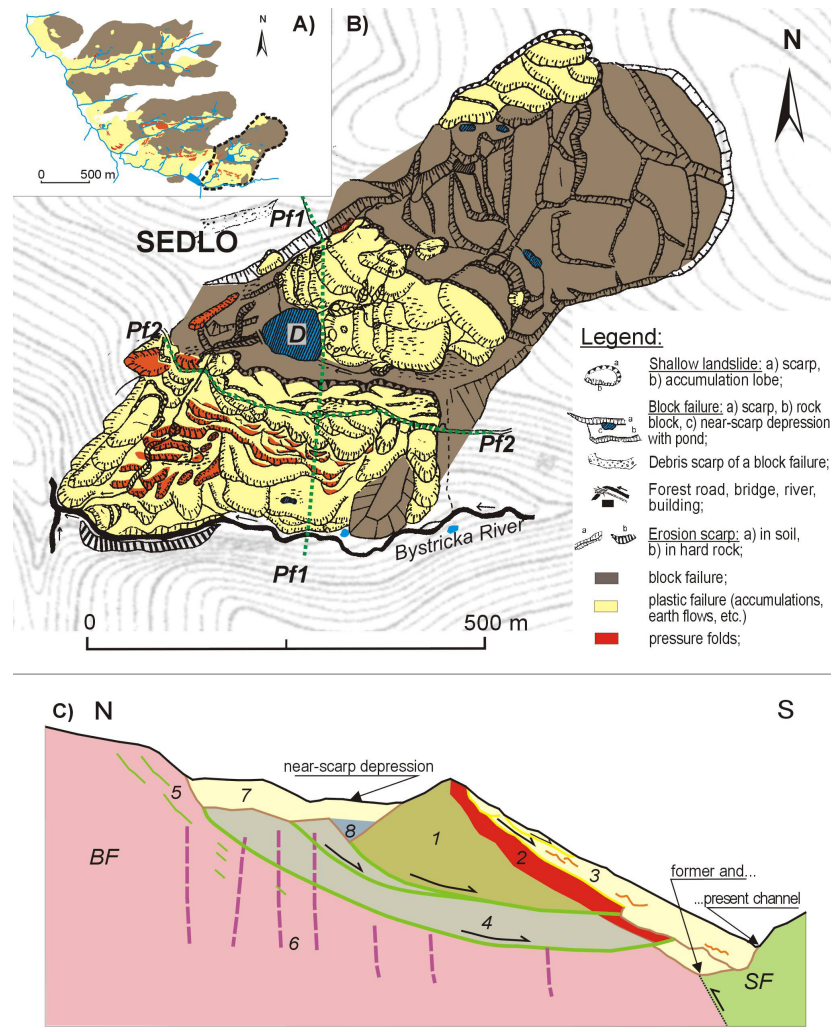

Fig. 6. Vaculov-Sedlo: (A) Geomorphic sketch of the VaculovSedlo deep-seated slope failure; The investigated area is surrounded by a dashed line; (B) Detailed geomorphic map of the investigated area; Ground Penetrating Radar profiles Pf1 and Pf2 are shown as well as the site of the dated sediments $(D) ;(\mathbf{C})$ Cross-sectional interpretation of GPR record along Pf1; $B F$-Beloveza Formation, $S F$-Solan Formation, 1-uppermost block, 2-tension zone at front of the rotated block, 3-active shallow translational landslide and its older accumulations, 4-lower rotated block, 5-unloading ruptures or new slip surfaces, 6-deeply weathered bedrock along subvertical faults, 7-accumulations of superposed shallow landslides, 8 -expected buried pond sediments.

limited financial support. The GPR record was checked by electrical resistivity methods, a dug hole, and hand-driven "Instorf" drilling and "Wire-line" drilling with G20 apparatus (at the Vaculov-Sedlo site only; depth of $26 \mathrm{~m}$ ).

Because it is expected that clays can influence the triggering of mass movements, we tried to obtain an overview of the clay mineralogy of the colluvial material. Non-oriented claysize particles, artificially oriented particles, and samples saturated with ethyleneglycol vapour were analysed using Philips $X$ 'Pert APD diffractograph with a $\mathrm{CuK} \alpha$ ray emitter, registration in range of $2^{\circ}$ to $75^{\circ} 2 \Theta$ by $1^{\circ}$ per min. The analyses were performed in the laboratories of the Geological Institute of the Czech Academy of Sciences, Prague. This method provides general and semi-quantitative mineralogical results, which are presented in Table 1.

Several dating and sedimentological methods were used for studying the evolution and dynamics of the mass movements. The most recent events were dated by a method 


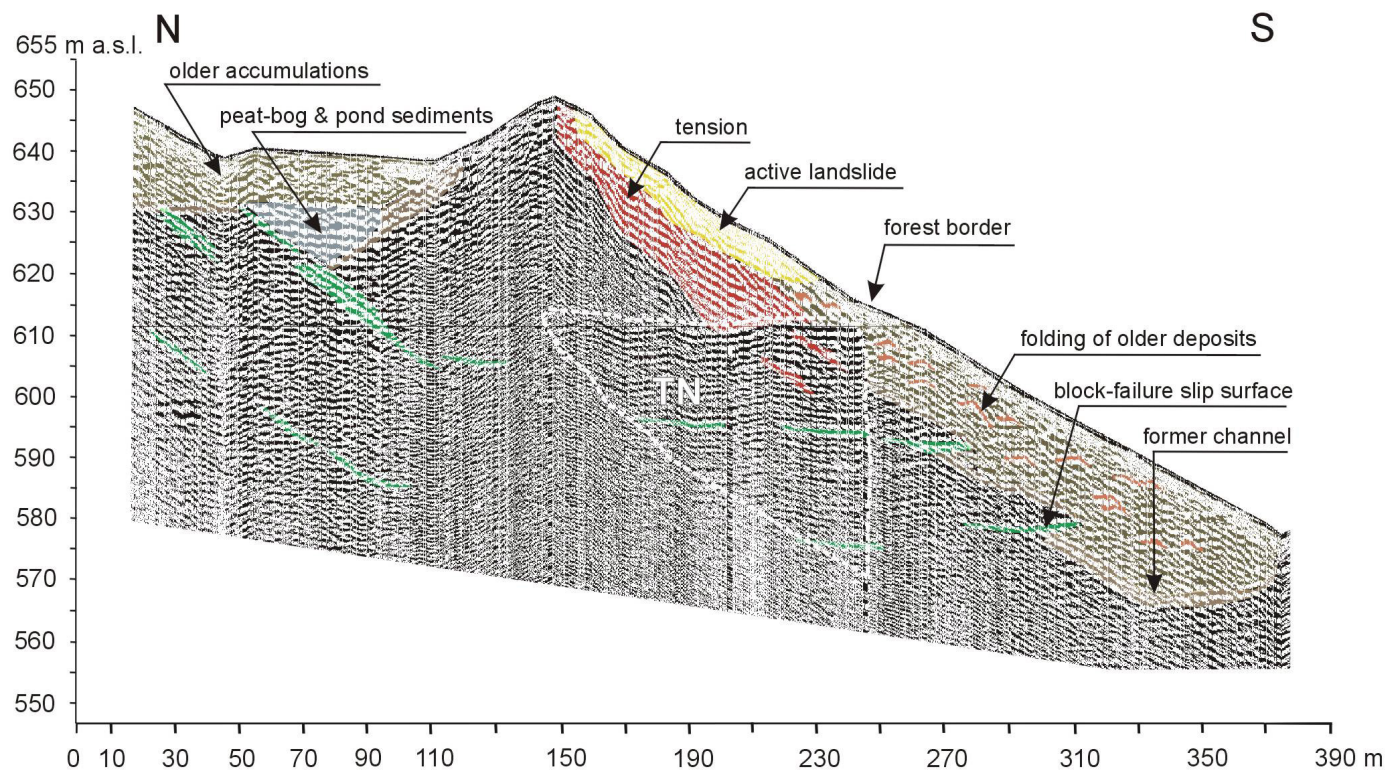

Fig. 7. Interpreted GPR record along the southern part of Pf1; TN-“tree noise”, i.e. surface reflectors from the forest border that mask real subsurface structure.

that we call dendroinclinometry. In fact, it is a kind of dendrogeomorphology of Schroder (1980). We studied inclined spruces, firs, and larches, which sensitively reflect landslide activity. Since the time when they became inclined, their tops have been growing vertically upward due to negative geotropism. Each landslide event was dated by counting year-accretion branches above the trunk flexure. By analysing large group of trees, we were also able to recognise the character of the failure: i.e. rotational block movement, pressure folding (Fig. 5), etc.

Sediments in landslide-related basins (e.g. in near-scarp depressions or behind landslide dams) were cored with Instorf hand-drill (Margielewski, 2001). The maximum depth we reached by this method was about $8 \mathrm{~m}$. The cores were macroscopically described. The samples of wood, peat, and pond or landslide-dam sediments were collected, and the cores were saved in boxes. We dated only typical horizons that represented pronounced sedimentation change, due to large sample amounts and episodic sedimentation in the basins. The sediments were dated indirectly by radiocarbon dating of wood buried in the basin. The ${ }^{14} \mathrm{C}$ datings were performed in laboratories of Minsk University (Belarus), where the activity of ${ }^{14} \mathrm{C}$ was measured with a GARDIAN $\beta$-counter.

Archaeological dating was performed by observing the failure of the defence circumvallation of the Lusatian-UrnField-Culture settlement at Kopce Hill (2,5 to $3 \mathrm{kaBP}$, Dohnal, 1988). The circumvallation crosses a crack that developed due to movement of the uppermost block.

\section{Slope-failure description, deep structure and develop- ment}

\subsection{Vaculov-Sedlo}

Because the Vaculov-Sedlo slope failure is very large (Fig. 6A), we focused our attention on a rotational block failure and its immediate surroundings within a large translational part in the eastern part (Fig. 6B). This area is strongly tectonically controlled by a $250 \mathrm{~m}$-wide NE-SW sinistral fault zone, which separated the bedrock and facilitated deep weathering.

The upper part of the translational failure (out of the focused area) consisted of asymmetrically back-tilted or sagged blocks of bedrock up to $200 \mathrm{~m}$ in diameter (Fig. 10). Both side margins followed limits of the fault zone, laterally from the general slope dip. The N-W side scarp is $15 \mathrm{~m}$ high and the S-E margin is partly formed by $2-4$-m-high steps at the block faces. Consequently, shallow and very active translational landslides have been triggered at the lowermost fronts of the rotated blocks. Their accumulations partly filled the scarp depression of investigated back-tilted blocks below (Fig. 6C). The investigated blocks were about $350 \mathrm{~m}$ wide by 100 and $80 \mathrm{~m}$ long, and they were superposed on each other. A set of two parallel shear zones has developed at base of the blocks, although the GPR reflectors are fragmentary at depths of more than $15 \mathrm{~m}$ (Figs. 6C and 7). However, a south-dipping shear zone is clearly observable to a depth of $30 \mathrm{~m}$ in the head area. The fragmentary GPR reflectors of the lower rock-block shear zone are recorded there at a depth of as much as $55 \mathrm{~m}$. We also recognized secondary slip surfaces parallel to main shear zones behind the scarp. These surfaces have probably developed due to unloading (Fig. 6C). 


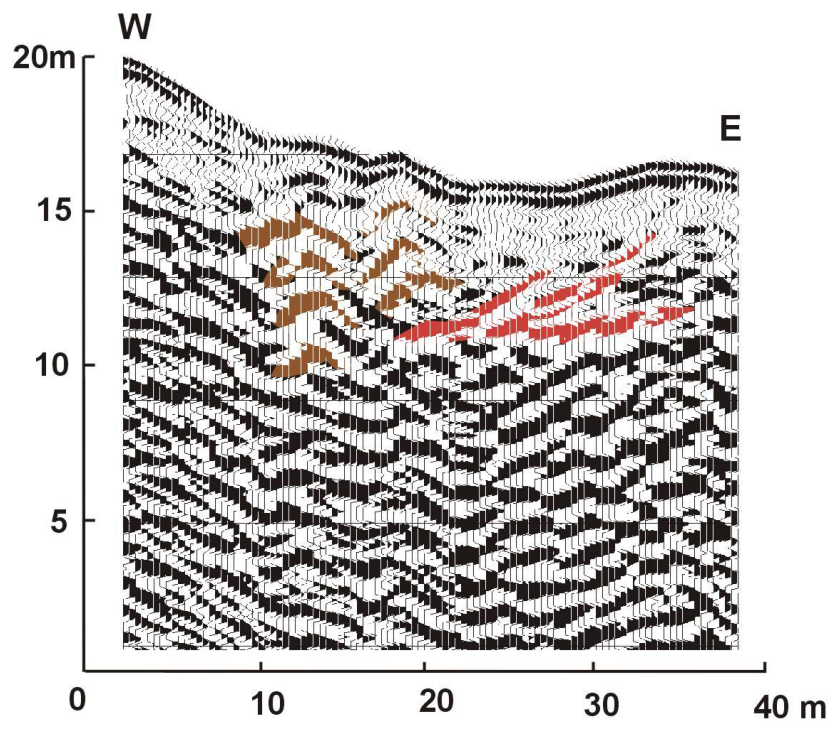

Fig. 8. Interpreted GPR record of a gravitational folding within old accumulations; See the "undulating" GPR reflectors in brown and slip surfaces in red.

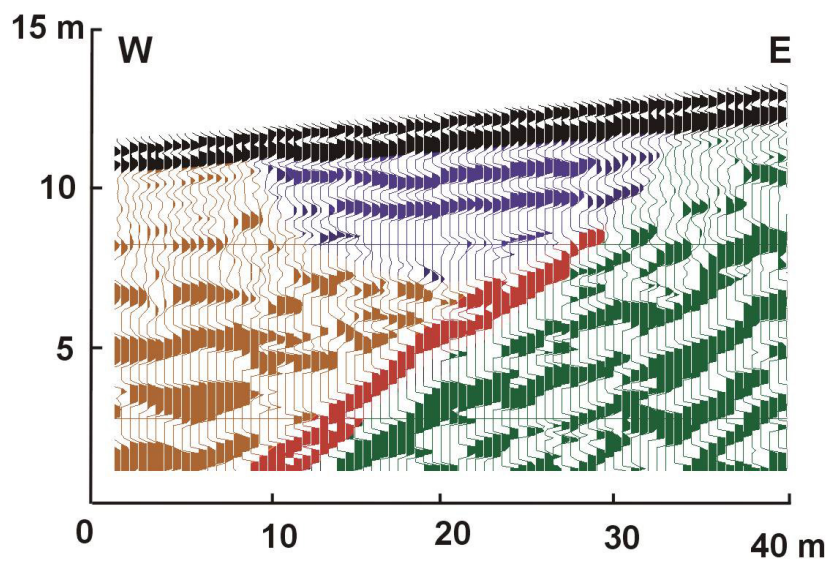

Fig. 9. GPR record of a subsequent shallow landslide crown at the eastern edge of the active secondary tranlational landslide-ASTL (eastern part of Pf2): blue-subsequent shallow landslide, red-slip surface of ASTL, brown-body of ASTL, green-mass of a slid block.

From the obtained record, we expect maximal depth of the base of blocks to be at 40 and $70 \mathrm{~m}$; the blocks are disrupted by a few longitudinal faults, probably caused by a different rate of rotation. The maximum rotation of the blocks is about $12^{\circ}$ and $27^{\circ}$. Behind them, a near-scarp (head) depression has originated. The depression is about 300 wide and up to 150 long, and it is "V"-shaped behind the superposed and most-rotated block (Figs. 6C and 7). By mean of lowfrequency GPR reflectors, we speculate on the existence of intensive weathering and water-saturation along sub-vertical faults below the depression to depth up to $55-60 \mathrm{~m}$. The eastern part of the depression was filled with several generations of up-slope accumulations of shallow landslide deposits (the accumulation thickness here is about $10 \mathrm{~m}$ ). Currently, there

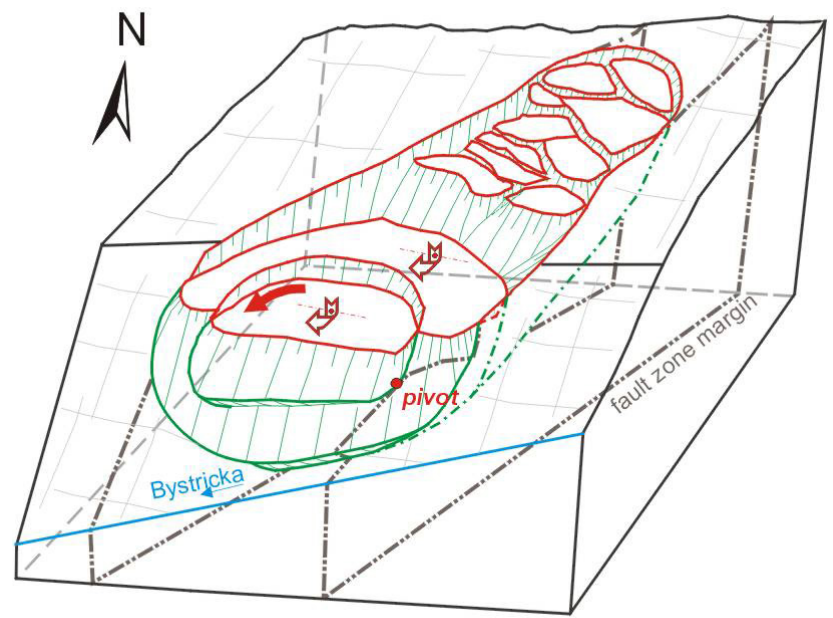

Fig. 10. A model of the block failure at Sedlo. It has developed along a fault zone, which enabled separation and deep weathering of bedrock. The upper blocks are just sagged or slightly back-tilted. The lower ones are rotated up to $12^{\circ}$ and $27^{\circ}$, and they are superposed on each other with an "onion-like" layered structure. The slip surface of the base block runs across the more competent sandstones of the Solan Formation at the lower eastern edge (see also Fig. 2). These sandstones act as a braking factor. They probably control activation and a slight sinistral horizontal rotation (full red arrow) of the superposed smaller block. The subsequent shallow failures at the front of the blocks have not been taken in account for better clarity.

is an artificial pond, called a "Sedlo", in the rest of the depression. The sedimentary fill of the western part of the depression consists of dark mud and brown peat from the present pond, and at least two layers of old colluvial accumulations with buried tree trunks, alternated with peat horizons to s depth of $7 \mathrm{~m}$ (the absolute bottom of the basin was not reached). The age of both of the colluvial horizons are $4280 \pm 130$ or $4490 \pm 1500^{14} \mathrm{C}$ yr BP, and $6100 \pm 250^{14} \mathrm{C}$ yr BP. The original age of the depression is not known because we were not able to reach its bottom. The depression is presently drained from the western margin of the block.

A secondary multi-storey translational landslide which was also re-activated in 1997, has developed at the front of the superposed block due to relative uplifting of its face by slow rotation. Low-frequency GPR reflectors provide evidence of tension and intensive weathering there (Fig. 7). The most weathered and exposed material formed the present shallow translational landslide with a 5-13 $\mathrm{m}$ deep base. The slide is about $300 \mathrm{~m}$ wide and $125 \mathrm{~m}$ long. Several other shallow landslides were triggered on the present translational slide during the subsequent few years after it had been deforested. These slides are 2 to $7 \mathrm{~m}$ deep, about $20-70 \mathrm{~m}$ long, and they usually present a " $U$ " cross-profile in the GPR record (Fig. 9).

The toe of the present secondary slide deposit did not reach the valley floor, but stopped above older deposition toes. The deposit is intensively weathered, water-saturated, and mixed. The overhanging base of a lower, rotated block and the buried 


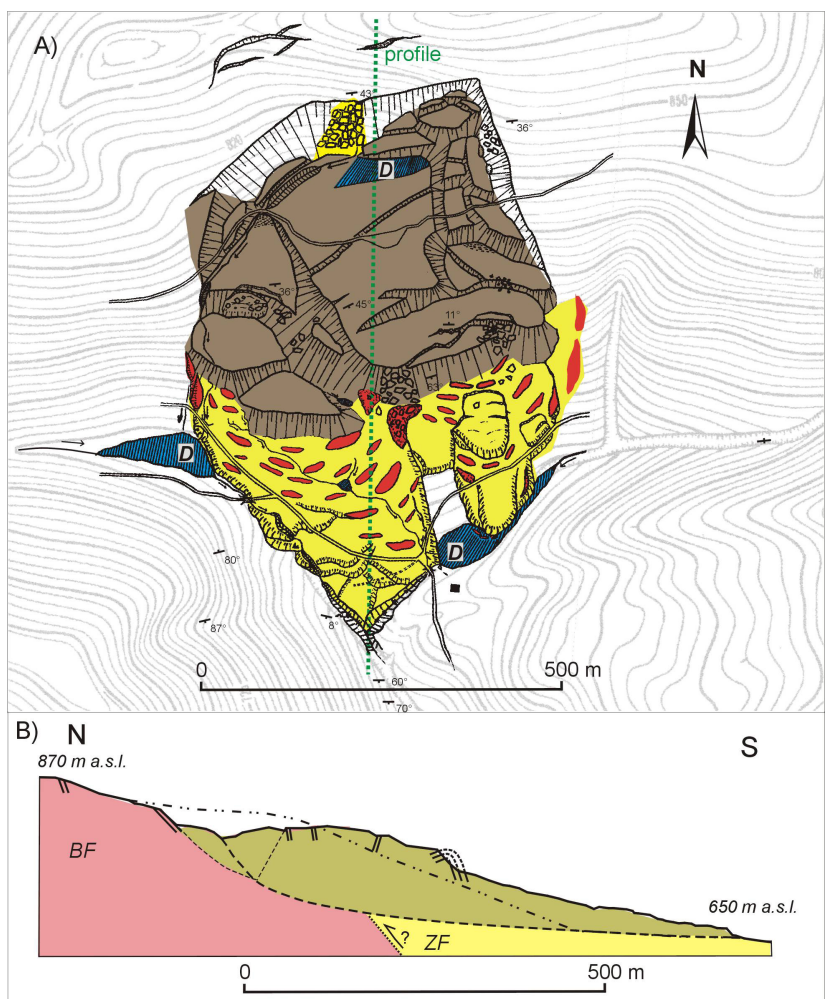

Fig. 11. Kobylska slope failure: (A) Geomorphic map; site of dated sediments $(D)$ is shown; (B) A sketch of the slope failure structure, longitudinal section. For legend see Fig. 6.

surfaces of a former slope and two river channels were identified by GPR 20 and $13 \mathrm{~m}$ deep below the deposits. The channel of the Bystricka River has been uplifted and moved about $50 \mathrm{~m}$ forward by the slide. The deposits have been compressed by the superposed active deposits; the GPR reflectors could be proof of the gravitational folding there (Fig. 8). Several pressure ridges and brachy-fold features up to $5 \mathrm{~m}$ high developed on the ground surface. They could be easily identified with dendrinclinometric analysis; the trees have been fan-like tilted there (in normal section to the fold axis, Figs. 5 and 13). The accumulations provided the substrate for a recent flow-shaped translational landslide about $200 \mathrm{~m}$ long near the western flank, which is elevated up to $5 \mathrm{~m}$ above its surroundings.

Although the GPR survey did not reach the ultimate base of the slope failure, the structure and development of the slope failure were recognized. Intense faulting, slip surfaces, tension and compression zones, and folding zones were verified, which made possible the formulation of a simplified model (Fig. 6C). Faulting has disrupted the bedrock and enabled very deep weathering in the $250 \mathrm{~m}$-wide tectonic zone, resulting in weakening of geotechnical strength properties and triggering of swelling pressures related to smectite (Forlati et al., 1998; Castelli and Scavia, 2001). Although the entire easternmost part is a translational slope failure, the lowermost rotated blocks of the slide have specific dynamics and development. They seem to have been more intensely

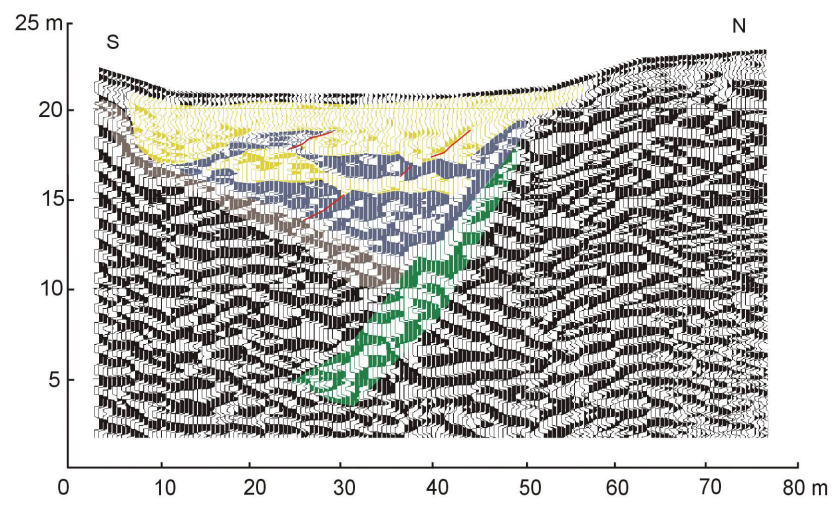

Fig. 12. Interpreted GPR record across the near-scarp depression in the upper portion of the Kobylska failure (situated on the crosssection line): green-slip surface, and brown-former surface of the main block (on the left-hand side); organic sediments (yellow) and prevailing clays (light blue horizons) are deformed.

rotated due to the presence of the erosional valley of the Bystricka river downslope. The blocks have rotated $12^{\circ}$ and $27^{\circ}$ (Fig. 10). The exact age when the rotation began could not be discerned, though it was certainly much earlier than $6100 \pm 2500^{14} \mathrm{C}$ yr BP, when one of the superposed shallow landslide deposits filled the near-scarp depression.

Where uplifting has occurred in the frontal parts of the rotated blocks, the bedrock has been affected by tension and intensive weathering. The uppermost part forms a shallow frontal landslide when the bedrock reaches critical shear stress; this process is repetitive. The frontal landslide toe deforms older deposits downslope, resulting in the development of pressure folds in these deposits. However, these folds may also have developed due to sinistral horizontal rotation of the superposed block (Fig. 10). As the area became deforested, several small landslides and mudflows occurred in the area of the frontal landslide.

\subsection{Kobylska}

The deep-seated Kobylska slope failure is considered to be the deepest failure of the present study. As a result, the GPR survey was limited only to shallow structures in the landslide, especially to landslide-related sedimentary basins. Most of our understanding of this slope failure has come from geomorphic and structural measurement surveys (Fig. 11A). A large rock block up to $500 \mathrm{~m}$ in dimensions has slid with a probably listric slip zone. This zone is estimated to be at a depth of $110 \mathrm{~m}$ (Fig. 11B). The block is fractured, with smaller scarps that are located on the front and at the sides. Small blocks are presently separating from the front of the main block because its top is elevated about $30-50 \mathrm{~m}$ above its foot. These blocks form secondary block slides ("diminishing ones" after Cruden and Varnes, 1996). A minor backinclined scarp runs laterally in the upper part of the main block. 


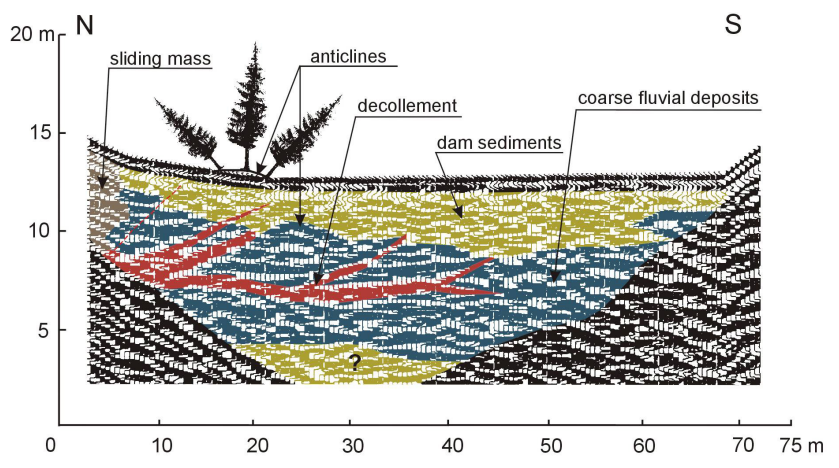

Fig. 13. Interpreted GPR record across the eastern palaeodam with lacustrine and coarse fluvial deposits that have been deformed by a shallow landslide from the north.

In the NE part of the landslide, a series of smaller blocks is superposed over the main one. The northernmost blocks have slid along a sandstone bedding plane $\left(148 / 43^{\circ}\right)$, which presently forms a $20 \mathrm{~m}$-high head scarp. In the central part of the scarp, the sandstone bed is broken due to extreme unloading. This bed has disintegrated into boulders up to $3 \mathrm{~m}$ in diameter. Five pseudo-karst caves (i.e. natural underground caverns accessible for men, developed due to different processes than solution; Panos, 2001) have developed between the boulders there. Some of the caves have been partly flooded by groundwater; springs issue from the lower caves.

Behind the main block, the flat surface of a swamp occurs, representing a former pond (Fig. 11A). This surface is about $80-100 \mathrm{~m}$ long and up to $50 \mathrm{~m}$ wide, and the basin is filled with sediment (peat, clay and organic detritus). A set of four core drillings has shown that the basin was at least $5.5 \mathrm{~m}$ deep. However, the individual horizons do not correlate with each other, and they have most probably been deformed by following displacement of the superposed blocks. A deformed fill was confirmed by the GPR survey (Fig. 12), but the total depth of the basin was about $10 \mathrm{~m}$. The flat surface of the basin is superposed over the rest of the head area in the west. This superposition was not caused by fluvial erosion, but was generated by subsidence of fragments of the main block by sinistral horizontal rotation, where further west, a triangular block had subsided. Two other lower blocks have slid as much as $45 \mathrm{~m}$ downslope in relation to the main block. These blocks form a secondary deep-seated translational failure.

The deposition part of the slide has been subjected to compression; a system of several pressure ridges and pressure brachy-anticlines has developed downslope from the displaced blocks. These pressure features are evidence of the block's failure, and their longer axes are oriented almost normally to the plane of maximum stress. At present, there are many pressure folds in the western secondary failure accumulations; it is the most active part. Moreover, there are almost no erosional cuts in the blocks, and the tree tilting is obvious. The accumulations of all secondary block failures are elevated about $3 \mathrm{~m}$ above their surroundings, and
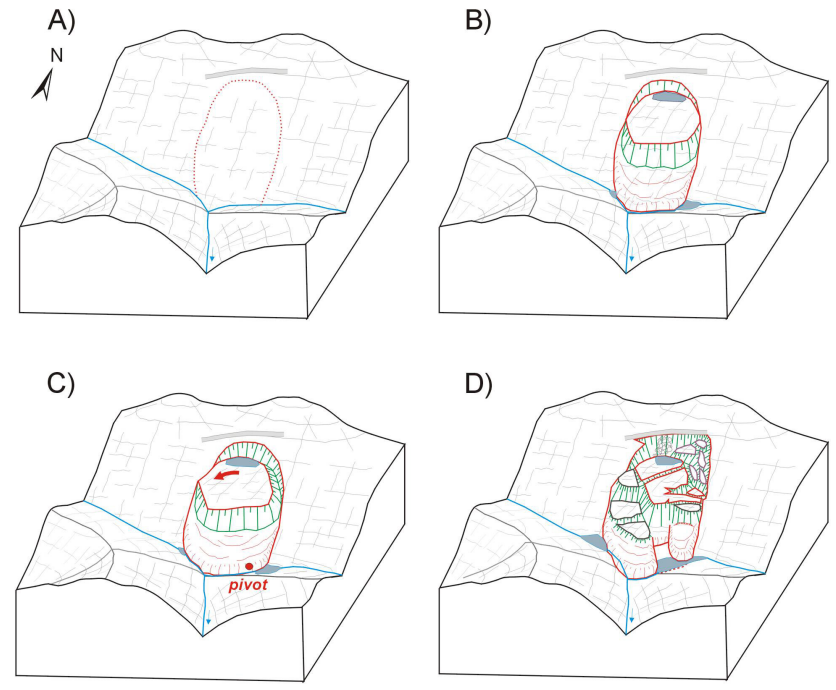

Fig. 14. A model of the Kobylska failure development: (A) stage before sliding, (B) sliding along a rotational or slightly translational slip surface, (C) asymmetrical blockage of the main block and its sinistral horizontal rotation, (D) two modes of secondary block sliding due to tension and unloading conditions: at front of the main block (brown blocks) and above the former scarp along bedding planes (violet ones).

have filled the valley below. Two landslide dams have developed. The dam basins are completely filled with sediments at present, and their surfaces reach 70 to $180 \mathrm{~m}$ and 60 to $80 \mathrm{~m}$. The sediments impounded by the eastern palaeodam are plastic and have been deformed by the accumulation front of a recently active landslide (Fig. 13). A system of pressure brachy-anticlines has developed there, with characteristic tree tilting on the lacustrine sediments surface. Several phases of the sedimentary fill of the basin were recorded, the total thickness of the last one being about $3 \mathrm{~m}$.

A paleo-geomorphic reconstruction of the development of the Kobylska landslide (Fig. 14) was formulated by considering that the sediments of the near-scarp basin had been deformed, that the present basin has an elevated position over the rest of the head area in the west, and that there has been a change of bedding orientation between the blocks. It was also necessary to study the structures of the individual blocks and the distribution of any recent activity. A large mass of the main block slid along a deep-seated, most probably listric, slip surface insequent to bedding at the end of the T-shaped Kobylska valley (Fig. 14B). The maximum displacement was about $120 \mathrm{~m}$. A near-scarp depression developed behind the main block at least $9080 \pm 95^{14} \mathrm{C}$ years BP (dating of tree trunk in lower part of the sedimentary fill). The sliding mass later became blocked at the opposite slope of the eastern tributary valley (Fig. 14C). This asymmetric stoppage caused sinistral horizontal rotation of the sliding mass by about $10^{\circ}$. In the eastern part of the crown, retrogressing blocks slid toward a near-scarp depression along the steep bedding planes (Fig. 14D). They deformed (folded) the peat and pond sediments of the depression after the rotation. Simultaneously, a 


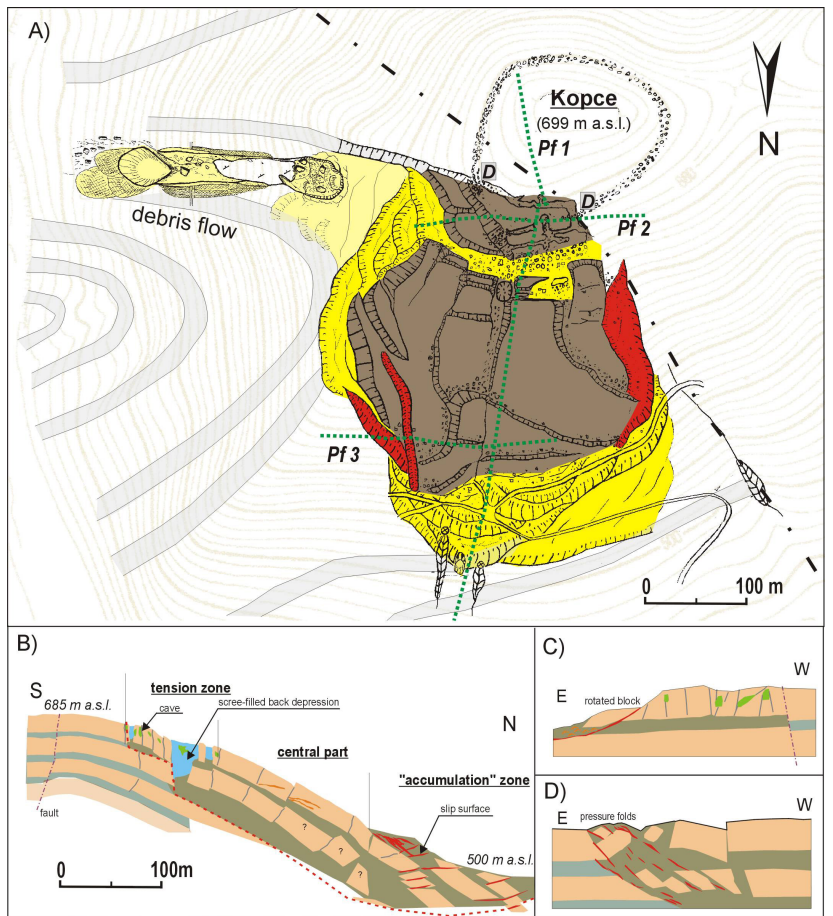

Fig. 15. Kopce slope failure: (A) Geomorphic map; GPR profiles Pf1 to Pf3 are shown as well as the location of dated sediments $(D)$, for legend see Fig. 6; (B) A cross section through the slope failure along Pf1; (C) A cross section through the slope failure along Pf2; (D) A cross-section through the slope failure along Pf3.

secondary smaller block landslide (with blocks $100 \mathrm{~m}$ in dimension) became activated at the western front of the main block, thus opening the near-scarp depression at the western part of the subsiding main block. Then, the former pond and peat-bog became located overhead (at least $2.9{ }^{14} \mathrm{C} \mathrm{ka} \mathrm{BC}$ ). Sedimentation of rather coarse wood and other organic matter is a proof of the distinct event. The secondary block landslide probably underwent several movement phases resulting in the damming of the western and eastern creeks, the last times being at $1065 \pm 140{ }^{14} \mathrm{C}$ years $\mathrm{BP}$ (eastern dam) and $704 \pm 120{ }^{14} \mathrm{C}$ years BP (western dam).

\subsection{Kopce}

The Kopce slope failure is, from a mechanical perspective, a unique case in the Western Carpathians. It has developed on the northern limb of the Luhacovice Member ramp anticline. Five parts of the failure have been distinguished by means of geomorphic inventory, surface mapping, and GPR survey, i.e. a central-block part, an accumulation (compression) zone, a secondary tension zone, a rotational slide, and a debris flow (Fig. 15).

The surface of the central-block part is composed of blocks of sandstone beds. These blocks are up to $150 \mathrm{~m}$ in size, about $20 \mathrm{~m}$ thick, and are limited by several meter-high steps on gravitational faults (Fig. 15A). The blocks are not back-rotated and their surfaces are regular, flat, and covered
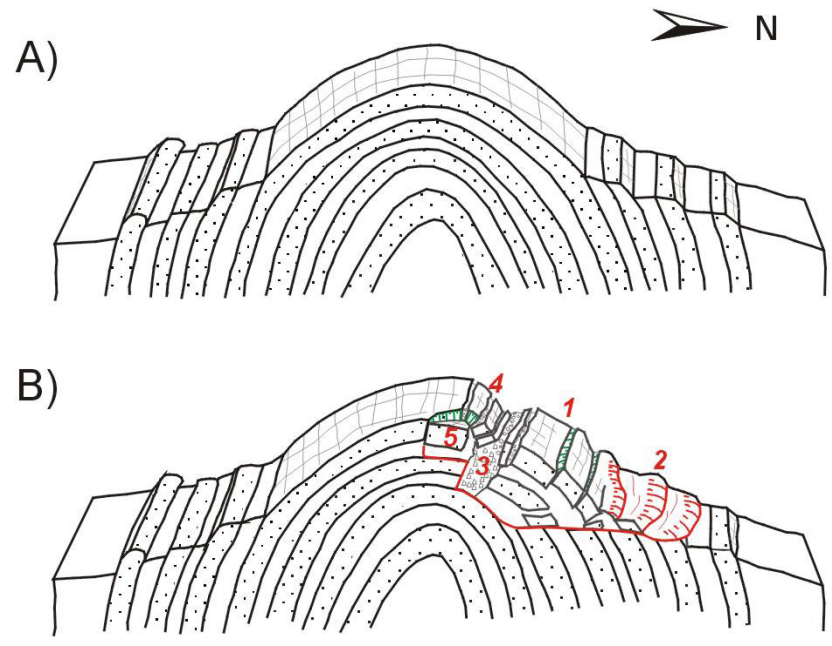

Fig. 16. A 3-D model of the Kopce slope failure structure (simplified): (A) original setting, (B) final stage: 1-central part, 2accumulation part, 3-near-scarp depression filled with debris, boulders and back-toppled blocks of the central part, 4-lateral-spread blocks, 5-rotated block failure.

with thin layers of debris. The total thickness of the blocks is up to $18 \mathrm{~m}$, and they slid onto the plastic and deformed shale layer below (Figs. 15B, C, D). The lower sandstone bed is probably also displaced, although the studied depth is below the GPR recognition limit. There are smaller blocks and rocks separated from the main blocks in the uppermost central part. Their bedding inclination differs from the main blocks, which suggests that they toppled opposite to the general surface slope. The western edge of the block is formed by a pressure ridge of mixed colluvium. The ridge is 1 to $1.5 \mathrm{~m}$ high, about $40 \mathrm{~m}$ wide and $200 \mathrm{~m}$ long (Fig. 15A, right part). At the eastern edge, there are side accumulation lobes, elongated fragments of blocks (incongruently inclined to the main blocks) and two pressure ridges (Fig. 15A, left part). The wider ridge limits the slope failure from the east (stable bedrock). It is up to $8 \mathrm{~m}$ high (from the outer side), 15 to $20 \mathrm{~m}$ wide and $90 \mathrm{~m}$ long. The narrower one is parallel to slope dip. This ridge is $120 \mathrm{~m}$ long, $10 \mathrm{~m}$ wide, and $3 \mathrm{~m}$ high. Both ridges have a nappe-like structure (Fig. 15D).

There are several lobes and rounded steps in the accumulation zone. These lobes and steps surround the blocks from below and are from 1 to $15 \mathrm{~m}$ high (highest on the southern side, where they are blocked by displaced relicts of a superposed and eroded sandstone layer). The plastic material has a nappe-like structure with a system of parallel slip surfaces in soft material (Fig. 15B). There are two springs at the foot of the lobes, which have formed an erosional channel $1.5 \mathrm{~m}$ deep.

In the upslope direction from the central-block part, an accumulation of boulders and debris occurs (with a $33 \mathrm{~m}$ long scree cave called "Krapnikova"). The deposit, which is about $120 \mathrm{~m}$ wide and $50 \mathrm{~m}$ long, represents the former nearscarp depression, which is up to $45 \mathrm{~m}$ deep and infilled in (Figs. 15B and 16). Laterally-spread sandstone blocks occur 


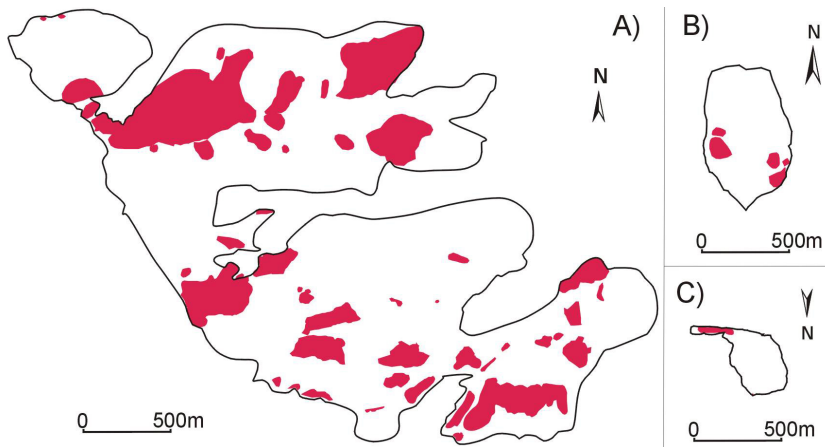

Fig. 17. Distribution of slope-movement activity since 1997: (A) Vaculov-Sedlo, (B) Kopce and (C) Kobylska slope failures.

upslope from the debris field. The area of lateral spreading is located at the site of sub-horizontal bedding near the top of the anticline. Most of the 13 pseudo-karst caves are situated between and within the spread blocks. Other geomorphic features also occur there, e.g. suffosion dolines due to piping, open cracks, rocky scarps, etc., predominantly oriented normal to the slope dip. The uppermost crack is crossed by a debris defensive mound of a prehistoric settlement of the Lusatian Urn Field Culture at two places (" $D$ " in the Fig. 15A).

Eastward from the spread blocks are two blocks from a rotational failure. The failure has developed at a place of horizontal bedding near the top of the anticline (Fig. 16). Mass movement has been oriented toward the location of maximum unloading (the Senice River cut in the E). The furthest accumulation lobes have been transmitted on the steep eastern slope by creeping.

A debris flow had developed on the eastern slope, about $60 \mathrm{~m}$ below the block slope failure (Fig. 15A). The most recent flow was about $258 \mathrm{~m}$ long; it moved in a valleylike depression in March 1999. This flow can be subdivided into a tension zone around the source area (an emptied amphitheatre-like depression), a transport track zone with an asymmetric trough on a sloping sandstone surface (an anticline limb), and an accumulation lobe zone with four old lobes and the present one. The basal surface of the flow occurred on the exhumed lower sandstone surface. Clearly developed slip-surface striations formed on the sandstone surface after sliding. These striations can be distinguished by their large range in direction $\left(40^{\circ}\right)$, different widths, and ragged surfaces resulting from crumbling of sandstone grains. The striations are still visible five years after the debris flow occurred. Lateral ridges occur to a height of about 1-2 m. Four ridges of different age can be distinguished on the left-hand side of the debris-flow track: the most recent one is internal, while the three external ones are older (at least 80 years old, based on dendrology dating).

The development of the Kopce slope failure began with the sliding of the anticline wing after the Senice River had cut deeply through the anticlinal ridge (Fig. 16A). Two superposed sandstone blocks of the "central part" had moved along the alternating plastic shale layers on the northern slope of
Kopce Hill (Fig. 16B). The movement approximately paralleled the bedding and it was slightly sinistral (with a different character of pressure folds on the sides). The maximum total displacement was $20-30 \mathrm{~m}$. An open crack developed behind the blocks that had slid. This crack became filled with boulders, debris, and toppled blocks from the surrounding slide blocks. The lateral spreading of the uppermost sandstone bed took place above this, where the bedding was subhorizontal. Though the area below the debris fill in the tension zone is currently inaccessible, we expect that it may be filled with near-scarp depression deposits. A small rotational block slide also developed near the top of the anticline eastward to the lateral spread. The bulged plastic material was mobilized on the steep eastern slopes by creeping. The rate of creeping has accelerated at the location where the bedding plane of the inner sandstone arc steepens, thus generating periodic debris flows (Baron, 2002). Nowadays, the source area is again being filled by colluvium, which will be the source for a future debris flow.

Although, there is lack of datable material, the Kopce slope failure should be older than 2.5 to $3 \mathrm{ka} \mathrm{BP}$, when the settlement of the Lusatian Urn Field Culture existed at Kopce Hill (Dohnal, 1988). The defensive circumvallation of that settlement crosses the uppermost crack at two places, but has not been markedly deformed by slope movements.

\section{Present-day activity: reflection of rainfalls in 1997}

It is quite instructive to compare rainfall data with slopefailure activity. An exceptional rainfall event occurred in 1997 in the area of the Czech Flysch Carpathians, during which precipitation values became extremely high from 5 to 8 July. Precipitation in excess of $380 \mathrm{~mm}$ was recorded during those four days. Such values are about four times higher than the total mean rainfall for July. The $6-8$ July rainfall event was followed by another one on 17-21 July (Pavlik and Sandev, 1997). The total July 1997 precipitation at the Valasske Mezirici station was $497.6 \mathrm{~mm}$ (70\% of the annual mean) and $549.6 \mathrm{~mm}$ at Roznov pod Radhostem (60\% of the annual mean) (Krejci et al., 2002). Both localities are situated close to the studied sites.

This extreme July rainfall event, the largest in the $20^{\text {th }}$ century for the Czech Republic (Pavlik and Sandev, 1997), had only a limited and isolated effect on the triggering of slope movements within the studied case sites (Fig. 17). The main indicators of activity were tree tilting, building damage, freshness of slope-failure features, and dilatometric measurements.

Although the distribution of the activity was rather isolated (Fig. 17A), several types of movement occurred in the Vaculov-Sedlo slope failure area, such as deep-seated blocktype rotational and translational slides, and shallow translational and planar slides on bedding planes or bulge and pressure folds. The main damage was observed on shallow, nonblock parts of active failures. In total, at least $0.12 \mathrm{~km}^{2}$ of 100 -yr-old forest was affected by mass movements, as well 
as about $800 \mathrm{~m}$ of local roads, several hundreds of meters of power lines, and eight houses were damaged or destroyed as a result of the 1997 rainfall. Besides those settlements damaged in 1997, other residential areas in the Bosova and the Malenov are in danger from possible future activity. These residential areas are located on the accumulation part of a deep-seated block slope failure.

Within the Kobylska slope failure (Fig. 17B), the most active area since 1997 has been a shallow secondary landslide within the accumulation zone of the diminishing block slope failure at the front of the SE side of the main block. In addition, block slides in the SE and SW portions of the main block have also been re-activated, though at a much slower rate. No present activity was observed in the area of main block, on the smaller blocks above, or in the Pokladnice cave.

A limited degree of re-activation was also observed in the Kopce slope failure. The central block part and the tensionzone pressure ridges revealed no surface indications of recent movements (Fig. 17C). Only a small shallow slide, about 10$15 \mathrm{~m}$ long, was triggered in the accumulation zone in 1997. Later, a debris flow was activated in 1999 after snow melting and intensive deforestation in its source area. Following its movement, the formation of distinct cracks around the emptied source area (the tension zone) revealed that the material is creeping and sliding down into the source area; thus, there is a clear tendency for the source area to be filled in again, preparing material for the next event.

\section{Discussion and conclusions}

Several methodologies have been suggested for the investigation of deep-seated slope failures (e.g. Agliardi et al., 2001; Clerici et al., 2002; Buccolini et al., 2002). The set of methods used depends on the purpose of the investigation, on geological, geomorphic, and climatic settings, and, of course, on financial support. In our study, we did not use photogrammetry and stereoscopy as proposed by Agliardi et al. (2001), due to dense forests cover. The main method applied in our study was detailed geomorphic mapping of individual slope-failure features. We suspect that this method is strongly influenced by subjectivity of the expert. But if it is used properly, it can offer a very good image of the slope-failure surface conditions and can be a very good base for subsequent field surveys. Geomorphic mapping was supported by dendroinclinometric analyses in forested areas and complemented by structural measurements. We later noted the deeper slope-failure structure by means of ground-penetrating radar (GPR). The strong advantage of GPR as an explanatory tool is the continual imaging of subsurface conditions, clearly detectable slip surfaces, shear zones, and weathered or water-saturated parts due to the contrast in relative dielectric permittivity (RDP) as related to clay and water content in the colluvium and bedrock (Conyers and Goodman, 1997). A strong disadvantage of GPR is the occasionally ambivalent interpretation of the record, especially when interpreted without any knowledge of the bedrock structure and with no consultations be- tween the geophysicist and the geologist. The GPR record is also very often made "noisy" by reflectors from vegetation lines and forest edges (Young and Sun, 2000). In this study, the depth of the GPR record reached as much as $40 \mathrm{~m}$, depending probably on water and clay content, contrast of RDP, and the power and frequency of applied antennae. However, this tool seems to be very powerful, in coordination with geomorphic surveys and especially with seismic surveys, which are planned to by applied here in the future.

Use of other methods of Quaternary geology, e.g. radiocarbon dating (Olssun, 1986) complemented with pollen analyses (Kneblova-Vodickova, 1966), dendroinclinometry or dendrogeomorphology of Schroder (1968), sedimentological analysis of slope-failure sediments (Nemec and Kazanci, 1999) and related basins (Margielewski, 2002), and archaeological observations is becoming more routine, and these techniques are becomming integral components of today's inter-disciplinary methodology. They seem to be necessary for the complex understanding of the slope-failure process, its geomorphic and climatic history, and risk evaluation (Schoeneich, 1991). In addition, subsequent testing by geotechnical analysis and numerical modelling should be included for the entire investigation (Moser, 2003; Rainone and Sciara, 2003). Results of our geotechnical surveys and numerical modelling of the case sites in the Flysch Carpathians are objectives of another paper (Baron et al., submitted ${ }^{1}$ ).

Such comprehensive methodology enabled us to recognize structure and to roughly reconstruct the development and kinematics of the three deep-seated slope failures. All three are situated within the mountainous relief of the Raca Unit of the Magura Nappe, which is tectonically very complicated, having a thin-skinned Upper Tertiary nappe structure of relatively weak Cretaceous and Lower Tertiary flysch rocks. Diversity of types of mass movements in the case sites of Raca Unit of the Magura Nappe seems to be greater than that of the deep-seated slope failures, described by Novosad (1966) or by Janos (2004) in the neighbouring Godula Development of the Silesian Nappe (mountain part of the Outer Flysch Nappe to the north of the Magura Nappe in Fig. 1). This part of the Silesian Nappe is composed, in general, of a monoclinal structure of thick-bedded sandstones and intercalated shales, slightly dipping to the SE, where deep-seated slope failures are mostly of planar.

All of the slope failures in our study are block-type. As "slope-failure blocks", we considered relatively intact blocks of bedrock with preserved original bedding and surface shape. They could be back-tilted, less usually forward-tilted, laterally displaced or sagged, and limited by scarps or cracks on the ground surface and slip surfaces or shear zones underground. As "block-type slope failures" we mean any slope failures, composed (usually in their upper part) of rotational, planar or translational blocks or lateral spreads. In the Czech

\footnotetext{
${ }^{1}$ Baron, I., Agliardi, F., Ambrosi, Ch., Crosta, G.B.: Numerical Analysis of Deep-Seated Mass Movements in the Magura Nappe; Flysch Belt of the Western Carpathians (Czech Republic), Natural Hazards and Earth System Sciences, submitted, 2004.
} 
landslide literature, such slope-failure blocks are called "kra" (Zaruba and Mencl, 1969). Recently, such blocks have been presented inter alia by Beetham et al. (2002). In all of the case sites, these blocks have been generators of the motion. They deform their foreground and side margins, resulting in development of pressure folds (pressure ridges of Beetham et al., 2002) or systems of pressure brachyanticlines. These pressure folds and accumulation toes form small-scale nappe-like structures within the accumulation zones (Fig. 5). At the frontal parts of deep-seated slope failures, relatively shallow secondary landslides develop ("diminishing ones" of Cruden and Varnes, 1996). They mostly originate due to local bulkage, uplifting or tension of the material consequently to activity of the broader slope-failure blocks, or by erosion activity of rivers. Such shallow landslides seem to be much more rapid and destructive ones than their deep-seated precursors. Similar cases of such subsequent rapid mass movements, related to deep-seated slope failures have been described by Agliardi et al. (2001).

The main factors influencing triggering and development of the entire deep-seated slope failures in this study remain the subject of discussion. Undoubtedly, geological structure, local topography, and specific flysch lithology and hydrogeology are prime factors (Rybar, 1999). Sub-horizontal bedding favours rotational failure (e.g. at Vaculov-Sedlo) and the development of pseudo-karst caves (at the Kopce slope failure). The combination of plastic and competent flysch layers is typical of areas in which slope failures develop in the Carpathians. A thin-bedded flysch, rich in claystones and broken sandstone layers, seems to act as a quasi-homogenous material on large scale. Therefore it becomes suitable for rotational failure, as in the Kobylska and the Vaculov-Sedlo slope failures. Also thick competent beds superposed on plastic shale often serve as substrate for rotational blockfailure, or for lateral spreading (e.g. the upper part of the Kopce landslide). Faulting facilitates slope failure not only as a surface of separation or a slip surface, but also by allowing deep weathering that causes weakening of the bedrock and the formation of swelling clays. The triggering of movement due to shrinking-swelling effect of swelling clays is not yet well understood. The decrease in cohesion and the friction angle when swelling occurs has been discussed (ReidSoukup and Ulery, 2002), as has the role of swelling pressures as triggering factors (Forlati et al., 1998; Castelli and Scavia, 2001). Human activities (such as deforestation) seem to directly trigger mostly shallow failures rather than deepseated ones.

Triggering of deep-seated landslides is usually caused by long-lasting rainfall rather than by the shorter, more-intense variety (Zezere and Rodrigues, 2002). All of the studied case sites for deep-seared failures are of prehistoric age. It is presumed that they originated during the humid phases of Early Holocene or during the Late Glacial as permafrost began to melt (Alexandrowicz and Alexandrowicz, 1999; Margielewski, 2002). The amount of water available in such conditions would have been much larger than that associated with the anomalous precipitation event of July 1997, when a relatively sporadic and isolated activation occurred within at the study sites. The cold and relatively dry period of the ice ages (full glacial) could be speculated as a time when deep-seated mass movements were halted in the Czech Flysch Carpathians, with shallow solifluction of the active layer probably masking former deep-seated landslide features. Predicting the future activation or reactivation of deep-seated mass movements is subject to similar degrees of uncertainty, as is the prediction of anomalous rainfall events.

Acknowledgements. We would like to thank our colleagues and friends who have helped us with providing this research by making the analyses, ancillary field works or by providing advise. The research was funded by the Ministry of the Environment of the Czech Republic (Project "Slope Failures in the CR"), by the University Development Foundation of the Czech Republic (Grant No. 742/2002), by the Grant Agency of the Czech Academy of Sciences (CEZ Z3-013912), and by the Regional Authority Zlin. Special thanks belong to R. L. Schuster for reviewing the English.

Edited by: L. Marchi

Reviewed by: M. Jaboyedoff, P. G. Nicoletti, and another referee

\section{References}

Agliardi, F., Crosta, G., and Zanchi, A.: Structural constraints on Deep Seated Slope Deformations kinematics, Engineering Geology, 59, 1-2, 83-102, 2001.

Annan, A. P.: Ground Penetrating Radar, Workshop Notes, Sensors \& Software Inc., 1997, 1091 Brevik Place, Mississauga, ON L4W 3R7, Canada, 1997.

Alexandrowicz, S. W. and Alexandrowicz, Z.: Recurrent Holocene Landslides: a Case Study of the Krynica Landslide in the Polish Carpathians, The Holocene 9, 1, 91-99, 1999.

Baron, I., Krejci, O., Cilek, V., Melichar, R., and Kirchner, K.: Geomorfologicke aspekty hlubokych svahovych deformaci na Vsetinsku, in: Sesuvy, clovek a krajina, - Elektronicky sbornik referatu z odborneho seminare, 16-18 April 2003 v HutiskuSolanci, edited by Baron, I., Klimes, J., CGS, Brno, 2003.

Baron, I., Cilek, V., Melichar, R., and Melka, K.: Jilove mineraly svahovych sedimentu vybranych hlubokych svahovych deformaci na Vsetinsku (Clay minerals in slope sediments of selected deep-seated landslides, Vsetin region, Moravia, Czech Republic), Geol. vyzk. Mor. Slez. v roce 2002, 10, 89-91, Brno, 2003.

Baron, I.: The changes of a flow landslide shape after two years, in: Landslides - Proceedings of the 1st European Conference on Landslides, Prague, Czech Republic, 24-26 June 2002, edited by Rybar, J., Stemberk, J., Wagner, P., Swets \& Zeitlinger, Lisse, 341-342, 2002.

Beetham, R. D., McSaveney, M. J., and Read, S. A. L.: Four extremely large landslides in New Zealand, in: Landslides - Proceedings of the 1st European Conference on Landslides, Prague, Czech Republic, 24-26 June 2002, edited by Rybar, J., Stemberk, J., Wagner, P., Swets \& Zeitlinger, Lisse, 97-102, 2002.

Buccolini, M., Sciara, N., and Mataloni, G.: An Integrated methodology for the study of a complex landslide: the case of Pescosansonesco (central Italy), in: Landslides - Proceedings of the 1st European Conference on Landslides, Prague, Czech Republic, 24-26 June 2002, edited by Rybar, J., Stemberk, J., Wagner, P., Swets \& Zeitlinger, Lisse, 117-122, 2002. 
Castelli, M. and Scavia, C.: A mechanical model for the analysis of planar landslides in swelling marls, in.: Proc. 15th Int. Conf. on Soil Mech. and Geotech., Istanbul, 27-31 August 2001, (Ed.) Publications committee of the XV ICSMGE, AA Balkema, Rotterdam, 1111-1114, 2001.

Clerici, A., Mandrone, G., Tellini, C., and Vescovi, P.: The Geomorphological and kinematic evolution of the Anzola Landslide, in: Landslides - Proceedings of the 1st European Conference on Landslides, Prague, Czech Republic, 24-26 June 2002, edited by Rybar, J., Stemberk, J., Wagner, P., Swets \& Zeitlinger, Lisse, 143-148, 2002.

Conyer, L. B. and Goodman, D.: Ground-Penetrating Radar: An Introduction for Archeologists, Altamira Press, Walnut Creek, 1997.

Crescenti, U., Sciarra, N., Gentili, B., and Pambianchi, G.: Modelling of complex deep-seated mass movements in the centralsouthern Marches (Central Italy), in: Landslides - Proceedings of the 1st European Conference on Landslides, Prague, Czech Republic, 24-26, June 2002, edited by Rybar, J., Stemberk, J., Wagner, P., Swets \& Zeitlinger, Lisse, 149-155, 2002.

Crosta, G.: Landslide, spreading, deep seated garvitational deformation: analysis, examples, problems and proposals, Geogr. Fis. Dinam. Quat. 19, 1996, 297-313, 1996.

Crosta, G., Zanchi, A.: Deep seated slope deformations: huge, extraordinary, enigmatic phenomena, in: Acta of the VIII International Symposium on Landslides, vol 1, 351-358, (Ed.) Bromhead, E., Cardiff, Great Britain, 2000.

Cruden and Varnes in Turner, A. K. and Schuster, R.L. (Eds.): Landslides - Investigation and Mitigation (Special Report 247), National Academy Press, 673 pp, Washington, D.C., 1996.

Dikau, R., Brundsen, D., Schrott, L., and Ibsen, M.L.: Landslide Recognition: Identification, Movement and Causes, John Willey \& Sons, $251 \mathrm{pp}, 1996$.

Dohnal, V.: Opevnena sidliste $\mathrm{z}$ doby popelnicovych poli na Morave (Fortified Settlements of the Lusatian-Urn Culture Age in Moravia), Studie Muzea Kromerizska, vol. 1988, 120, Kromeriz, 1988.

Forlati, F., Lancellota, R., Scavia, C., and Simeoni, L.: Swelling processes in sliding marly layers in the Langhe region, Italy, in.: The Geotechnics of Hard Soils - Soft Rocks, Proc. Int. Symp., Napoli, 12-14 October 1998, edited by Evangelista and Picarelli, Balkema, Rotterdam, 1089-1099, 1998.

Janos, V.: Svahove deformace severni casti Radhostskeho hrbetu v Moravskoslezskych Beskydech, Zpr. Geol. Vyzk. v roce 2003, Praha, 63-64, 2004.

Kneblova-Vodickova, V.: Paleobotanicky vyzkum raseliniste v Beskydech, Vestnik UUG, Praha, 41, 271-278, 1966.

Krejci, O., Baron, I., Bil, M., Jurova, Z., Hubatka, F., and Kirchner, K.: Slope movements in the Flysch Carpathians of Eastern Czech Republic triggered by extreme rainfalls in 1997: a case study, Physics and Chemistry of the Earth, Pergamon, 27, 1567-1576, 2002.

Korup, O. and Crozier, M.: Landslide types and geomorphic impact on river channels, Southern Alps, New Zealand, in: Landslides - Proceedings of the 1st European Conference on Landslides, Prague, Czech Republic, 24-26 June 2002, edited by Rybar, J., Stemberk, J., Wagner, P., Swets \& Zeitlinger, Lisse, 233-238, 2002.

Margielewski, W.: Late Glacial and Holocene Climatic Changes Registered in Landslide Forms and their Deposits in the Polish Carpathians, in: Landslides - Proceedings of the 1st European Conference on Landslides, Prague, Czech Republic, 24-26
June 2002, (Eds.) Rybar, J., Stemberk, J., Wagner, P., Swets \& Zeitlinger, Lisse, 399-404, 2002.

Margielewski, W.: Late Glacial and Holocene Climatic Changes Registered in Forms and Deposits of the Klaklowo Landslide (Beskid Sredni Range, Outher Carpathians), Studia Geomorphologica Carpatho-BalcanicaKrakow, 35, 63-79, 2001.

Moser, M.: Geotechnical measurements for assessment of the kinematic and long-term behaviour of unstable mountainsides, in.: Geotechnical Measurements and Modelling. - Proceedings of the International Symposium on Geotechnical Measurements and Modelling, 23-25 September 2003, Karlsruhe, Germany, edited by Natau, O., Fecker, E., Pimentel, E., A.A. Balkema, 217-223, 2003.

Moser, M., Meier, H., Lotter, M., and Weidner, S.: Geotechnical aspects of deep-seated mass movements in Austria, in: Landslides - Proceedings of the 1st European Conference on Landslides, Prague, Czech Republic, 24-26 June 2002, edited by Rybar, J., Stemberk, J., Wagner, P., Swets \& Zeitlinger, Lisse, 423-430, 2002.

Nemcok, A.: Gravitacne svahove deformacie vo vysokych pohoriach slovenskych Karpat (Gravitational Slope Deformations in High Mountains of the Slovak Carpathians), Sbornik Geol. Ved, HIG 10, 7-38, 1972.

Nemcok, A., Pasek, J., and Rybar, J.: Deleni svahovych pohybu (Mass movement classification), Sbornik Geol. Ved, HIG 11, 77 97, 1974.

Nemec, W. and Kazanci, N.: Quaternary colluvium in west-central Anatolia: sedimentary facies and paleoclimatic significance, Sedimentology 46, 139-170, 1999.

Novosad, S.: Poruseni svahu v godulskych vrstvach Moravskoslezskych Beskyd (Slope failures in Godula Member of Moravskoslezske Beskydy Mts.), Sbornik Geol. Ved, HIG, Praha, 5, 71-86, 1966.

Olssun in Berglund, B. E.: Handbook of Holocene Palaeoecology and Palaeohydrology, John Wiley \& sons, 895 pp, 1986.

Panos, V.: Karsologicka a speleologicka terminologie (Explanatory Multilingual Dictionary), Knizne centrum, Zilina, 352 pp, 2001.

Pavlik, J. and Sandev, M.: Synoptic assessment of weather situations during the July 1997 floods, Meteorological Bulletin, Praha, 50, 6, 164-171, 1997.

Picha, F. J., Stranik, Z., and Krejci, O.: Geology and Hydrocarbon Resources of the Outer West Carpathians and thei Foreland, Czech Republic, in.: The Carpathians: Geology and Hydrocarbon Resources, edited by Golonka, J., Picha, F. J., AAPG Memoir, in press, 2004.

Rainone, M. L. and Sciara, N.: A multidisciplinary integrated approach to geological and numerical modelling of the Lodrone landslide (Oriental Alps, Trentino Region, Italy), in: Geotechnical Measurements and Modelling. - Proceedings of the International Symposium on Geotechnical Measurements and Modelling, 23-25 September 2003, Karlsruhe, Germany, edited by Natau, O., Fecker, E., Pimentel, E., Balkema, A. A., 225-230, 2003.

Reid-Soukup, D. A., Ulery, A .L.: Smectites, in: Soil Mineralogy with Environmental Applications, edited by Dixon, J. B., Schulze, D. G., Soil Science Society of America, Inc. Madison, USA, 467-499, 2002.

Rybar, J.: Rozbor pricin zvyseneho vyskytu svahovych deformaci v Ceske republice v cervenci 1997 (Analysis of High Landslide Occurrence in Czech Republic in July 1997), Geotechnika, Praha, 2, 7-14, 1999. 
Rybar, J., Vilimek, V., and Cilek, V.: Process analysis of deep slope failures in Ceske Stredohori neovolcanites, Acta Montana IRSM CAS CR, Prague, AB8, 115, 39-46,2000.

Schoeneich, P.: La datation des glissments de terrain, in.: Landslides, edited by Bell, Balkema, Rotterdam, 205-212, 1991.

Schroder, J. F.: Dendrogeomorphology: review and new techniques in tree-ring dating, Progress in Physical Geography, 4, 161-185, 1968.

Schuster, R. L. and Wieczorek, G. F.: Landslides triggers and types, in: Landslides - Proceedings of the 1st European Conference on Landslides, Prague, Czech Republic, 24-26 June 2002, edited by Rybar, J., Stemberk, J., Wagner, P., Swets \& Zeitlinger, Lisse, 59-78, 2002.

Ter-Stepanian, G.: Type of depth creep of slopes in rock masses, Problems Geomech., 3, 49-69, 1966.

Yamada, Y., Ueda, S., Kaneda, K., Baba, K., and Matsuoka T.: Analogue and Digital modelling of Accretionary Wedges, Abstracts of 32nd International Geological Congress, Florence, Italy, 2028 August, 2004.
Young and Sun in Beres, M., Green, A. G., and Pugin, A.: Diapiric Origin of teh Chessel-Noville Hills of the Rhone Valley Interpreted from Georadar Mapping, Environmental and Engineering Geoscience 6, 2, 141-153, 2000.

Zaruba, Q., Fencl, J., Simek, J, and Einstein, Z.: Rozbor sesuvu u Dnebohu, Sbornik geologickych ved, HIG 5, 141-160, 1966.

Zaruba, Q. and Mencl, V.: Sesuvy a zabezpecovani svahu (Landslides and their control), Academia, Praha, 222 pp, 1969.

Zezere, J. L. and Rodrigues, M. L.: Rainfall Tresholds for Landsliding in Lisbon Area (Portugal), in: Landslides - Proceedings of the 1st European Conference on Landslides, Prague, Czech Republic, 24-26 June 2002, edited by Rybar, J., Stemberk, J., Wagner, P., Swets \& Zeitlinger, Lisse, 333-338, 2002.

Zischinsky, U.: Über Sackungen, Rock Mech. 1, 1, 30-52, 1969. 